\title{
Feminisme i amistats arreu del món: passions quotidianes en català
}

\author{
Laura Stumpp \\ Philipps-Universität Marburg
}

Rebut: 21 de febrer del 2020

Acceptat: 1 de juny del 2020

Quan vaig començar a aprendre català, no m'imaginava la passió que m'acabaria despertant un temps després. Sempre $m$ 'ha agradat aprendre llengües, però al principi vaig fer català com a assignatura optativa dels meus estudis, ja que era probable que anés a Catalunya per fer-hi unes pràctiques. I, des de la primera classe, la meva motivació per aprendre'l no ha parat de créixer. M'he adonat que per endinsar-me en una llengua necessito tres pilars: primerament, he de lligar-la a tants àmbits de la meva vida com sigui possible; segonament em cal fer amistats o altres tipus de connexions amb catalanoparlants; per últim, he de combinar les meves altres passions amb (l'aprenentatge de) la llengua. Pel que fa als mètodes, necessito tècniques diferents en espais diferents. A continuació ho explicaré amb més detall.

Com que no visc als Països Catalans, m'ha anat molt bé trobar mitjans de comunicació en català per integrar-los a la meva vida quotidiana, per estar en contacte amb la llengua més o menys cada dia, encara que només siguin cinc minuts d'escoltar una cançó o les notícies a la ràdio mentre em rento les dents. Com que les meves passions, entre altres, són el feminisme i l'escriptura (i sobretot l'escriptura feminista!), és una gran motivació explorar què hi ha en català. Fins ara he aconseguit trobar moltes coses que em donen molta alegria i, per tant, moltíssima motivació per aprendre la llengua. Per exemple, trobo divertit i empoderador cantar i ballar amb les cançons de Roba Estesa o Pupil.les; també m'agrada esmorzar escoltant el podcast Les dones $i$ els dies, emocionar-me mirant la sèrie Les de l'hoquei, i escoltar o llegir entrevistes de la Bel Olid; així mateix, em fascinen les conferències de Kosmopolis.

Quant a les classes i els espais socials, aquí importa el que he dit abans de tenir espais i temps distints per practicar coses diferents. O sigui, per aprendre un nou temps verbal o noves estructures, necessito exercicis repetitius i estructurats de manera clara. També m'ajuda molt visualitzar les regles i ordenar el vocabulari o expressions segons el seu significat o amb dibuixos. Pel que fa a la pràctica oral, hi ha diversos tipus d'exercicis que em van bé: per una banda, exercicis amb correccions precises; per l'altra, també m'ajuda tenir ocasions per poder parlar de manera distesa, sense interrupcions per cada error que cometi, com per exemple al Cafè català (Stammtisch). De la mateixa manera, llegeixo llibres de lectura fàcil i n'analitzo les estructures i paraules amb molta atenció, però també m'agrada llegir per plaer llibres juvenils o feministes, sense parar-me a pensar en cada paraula nova que trobo.

Com que m'agrada molt l'escriptura creativa, gaudeixo molt escrivint en català (encara que faci molts errors). Per aquest motiu, vaig participar en el concurs de microrelats de l'Institut Ramon Llull (IRLats) i vaig ser immensament feliç quan em van comunicar que l'havia guanyat, i que podria participar en el Campus universitari de la llengua catalana a Girona i Andorra. En aquest campus vaig conèixer gent d'arreu del món i vaig anar a classes cada dia, 
vaig assistir a xerrades, vaig fer excursions i visites culturals... Gràcies a aquesta estada lingüística el meu català ha millorat molt $i$, a part d'això, ara tinc molts més contactes amb qui parlar català. Aquestes amistats internacionals, connectades per aquesta llengua tan bonica i per tants records conjunts, han afegit un nivell emocional al català encara més alt. Ja puc dir que el català forma part de la meva vida diària, de les meves passions i amistats -i soc molt feliç de formar part del món catalanoparlant! 